\title{
MYTHOLOGICAL EPIC AND CHIVALRIC FICTION IN MODERATA FONTE'S AND LUCREZIA MARINELLA'S POEMS
}

\author{
ÉPICA MITOLÓGICA Y FICCIÓN CABALLERESCA EN LOS POEMAS \\ DE MODERATA FONTE Y LUCREZIA MARINELLA
}

Sandra Plastina

\begin{abstract}
This article focuses on Lucrezia Marinella's L'Enrico, ovvero Bisanzio acquistato (1635) and Moderata Fonte's Tredici canti del Floridoro (1581). Marinella's epic, or 'heroic,' poem belongs to a genre not well represented in women's writings, while Fonte's work is the first original chivalric poem written by a woman, an Italian woman who grappled with epic and chivalric romance. These genres were so elite and laborious that they discouraged all but the most enterprising writers of either sex. The female warriors of epic, the women's aptitude for martial arts, and the increasing openness to female involvement in battle correspond to a shifting emphasis in warfare from physical force to mental agility and astuteness. No attempt will be made here at a comprehensive treatment; rather the focus of the article will be on the question of how women in this period responded to what might be broadly termed the gender politics of chivalric works.
\end{abstract}

KEYWORDS: Moderata Fonte, Lucrezia Marinella, Gender roles, Gender attitudes, Fiction, Epic, force (physical and mental)

\section{RESUMEN}

En este artículo se estudian L'Enrico, ovvero Bisanzio acquistato (1635) de Lucrezia Marinella y los Tredici canti del Floridoro (1581) de Moderata Fonte. Tanto L'Enrico, un poema épico o 'eroico', como el Floridoro, el primer poema caballeresco compuesto por una mujer en el Renacimiento italiano, se adscriben a géneros literarios que por su carácter elitista y por su laboriosidad solo atraían a los autores más capaces de la época, independientemente de cuál fuera su sexo. En ellos, la épica de las mujeresguerrero, su aptitud para el arte de la guerra y la creciente apertura hacia su inclusión en confrontaciones bélicas corresponde con una deriva del énfasis en la fuerza física a la agilidad mental y a la astucia como cualidades primordiales para el arte de la guerra. 
Estas páginas no nacen con vocación de ofrecer un tratamiento comprehensivo de estos problemas, sino que más bien se ocupan de cómo las mujeres del Renacimiento abordaban lo que podríamos denominar «políticas de género» en la ficción caballeresca.

PALABRAS CLAVE: Moderata Fonte, Lucrezia Marinella, roles y actitudes de género, ficción, épica, fuerza (física y mental)

During the sixteenth and seventeenth centuries, some women writers who were representative of Italian literature of that period, questioned Boccaccio's assumption that women's physical weakness was accompanied by intellectual inferiority. Through later treatises, they demonstrated that women's physical weakness could inversely become the gauge of their intellectual superiority. The canon of the strong warrior women was developed in Western Europe during the fourteenth and fifteenth centuries. The female version of the Nine Worthies in literature and arts was called the Nine Worthy Women (Les Neuf Preuses). It was a less standard, occasionally varying list of names first primarily containing ancient heroines from the Theban Cycle or Amazon queens (Sinope, Lampeto, Penthesilea) and a Scythian empress called Tomyris who defeated Cyrus the Great. The trope of valiant warrior women was a source for Renaissance visual artists. For instance, in the woodcut series by Hans Burgkmair the Elder, a sixteenth-century German painter, we find the depiction of three Pagan, three Biblical (Esther, Judith, Jahel), and three Christian "heroines," one of whom was St. Elisabeth of Hungary (Papp 2016).

The figures of Amazon and Virago Amazons, together with the biblical female figures who fulfilled God's will, were important participants in the medieval trope of strong women, and thus an unequivocally positive attitude was maintained towards them. However, opinion about the Amazons was ambivalent partly because their actions and habits contradicted the accepted patterns of female behavior, and thus opposed the order of the world created by God. This disdain was based on the notion of the cruel and immoral, promiscuous Amazons, though a parallel trend also existed, which has been passed down to us in the Troy and Alexander Romances (Alexanderroman), that portrayed the characters of the brave Penthesilea with her virgin sisters in arms who gave help to Troy, the Amazon queen Thalestris, or the valiant and virtuous Camilla of the Volsci in the Aeneid - the Latin equivalent of the Greek Penthesilea-, whom Aeneas Sylvius Piccolimini (1405-1464, later Pope Pius II) compared to Jeanne d'Arc (Reinle, 2000). In his De ortu et historia Bobemorum, written around the middle of fifteenth century, Piccolomini tells the story of the Bohemian Amazons, Crocaus, Libussa, 
and Primislaus to relate the actions of a group of Bohemian warrior maidens whose way of life and behaviour appealed to him. These Amazons are led by the rebellious Valasca, a monstrous sorceress, sexually promiscuous and blood-thirsty.

Though women in the Renaissance played a more significant role in intellectual and political life than they had previously, many authors were of the opinion that only in exceptional circumstances could they become exemplary heroines, "viragoes" comparable to men. Most of these cases dealt with crossing gender lines, which could manifest in wearing men's clothing, accomplishing brave deeds, and assuming traits typically attributed to men; they also portrayed virtues like extraordinary physical or mental strength and skill in exercising power (Stoppino 2013, p. 207).

The figure of the warrior woman as represented in the Italian chivalric epic can be used as a privileged site from where many of the conflicts surrounding gender constructions in the early modern period are revealed. The Amazon, as a figure of conflict and, as we shall see, of conflict resolution, is a valuable object of study in this context. The presence of the Amazon in early modern literature, from the references by women writers to the central characters of the epic chivalric poems, is pervasive and contradictory. For these writers, the Amazon is often a mirror image, a term of comparison posited both by the women themselves and by their male counterparts.

In this instance, the comparison with an Amazon is at the same time empowering and diminishing. If likening a woman writer to a warrior woman depicts her as the strong counterpart to the male author in a predominantly male world, the usual connotation is that the Amazon is "man-like" beyond her sex. On the other hand, the Amazon as a female warrior in the chivalric epic fulfills different representational needs, setting up a number of dichotomies. As an unbridled foreign warrior, she can represent the savage alternativity of the past; as a beautiful opponent, she can be the medium for the appropriation of femininity by men. Her embodiment of the conflict between war and love epitomizes the generic distinction between epic and romance. She seemingly challenges gender roles, yet her main function is to relieve the homosocial tension of war and combat. These contradictions go the heart of the conflicted construction of gender in these texts and in their sociohistorical context. As Stoppino argues: "the representation of conflict is powerful site for the exploration of contradictions and distinctions in the representations of early modern gender construction" (Id., p. 235). To elucidate this point about gender-based contraditions, it is important to analyse three representations of conflict in Renaissance chivalric epic: the battle scene, the unmasking of gender, and the containment of the woman warrior. 
Clorinda in the Gerusalemme Conquistata (Jerusalem Delivered XII, 64), the last heroine of this genre, embodies a series of qualities that were crucial to the female warrior from the very beginning of the Renaissance tradition. She couples the classical Amazon figure with the irreducible alterity of the giantess of the preceding tradition, following representational patterns that link these figures to the savage women of the New World, which were very popular at the time (Ernst 2014, pp. 159-163).

Even the most perfunctory consideration of women's literature of the fourteenth through seventeenth centuries reveals a surprising number of women writing about warfare. As other researchers have already suggested, these women authors do not form any sort of unified "feminine voice" about war, but they often inscribe themselves within one or more of the competing feminine discourses of war, nicely categorized by Jean Bethke Elshtain, in Women and War $(1995)^{1}$ as the discourses of the pacifist, the civic mother, or the mythic Penelope awaiting her soldier-husband's return.

Recent studies have demonstrated how the intersection of war poetry and love lyric was treated by more than fifty women poets in the sixteenth century who wrote on war, not to mention the numerous women who wrote letters, diaries, chronicles, and treatises and felt compelled to write about their own experiences of living in war-torn lands. When Italian women writers started to write romances of chivalry in the sixteenth century, they had a ready-made topos to explore. Given their particular interests they soon started to examine the dynamics that the relationship between female twins could produce in a woman-friendly fictional world (Miller, Yavneh, 2016).

Moderata Fonte (Venice, 1555-1592), for example, although apparently concerned with the adventures of the knight Floridoro in her Tredici canti delFloridoro, gives more space and depth of characterization to the woman warrior Risamante, whose quest to recover the inheritance sue is due and the daughter of the king of the Armenia leads her to fight her identical twin, Bioandura, the ruler's sole heir (Finucci 2006, p. 209). Evident in the early modern example of Bradamante

1 Jean Bethke Elshtain has identified the influence of competing traditions of the feminine in warfare, including among others, Plutarch's Spartan mothers, where mothers encourage heroic acts of militarism, as well as the non-combatant "Beautiful Soul" who is in need of protection from a warrior man. These myths serve to recreate and secure women's social position as noncombatants and men's identity as warriors. Elshtain demonstrates how these myths are undermined by the reality of female bellicosity and sacrificial male love, as well as the moral imperatives of just wars. 
and Ricciardetto from Ariosto's Orlando furioso, the relationship between twins is not only a frequent means for exploring a broad variety of themes in Renaissance literature, but it is also one of the clearest and most common expressions of the complex world of sibling ties in early modern culture. The story of the donna guerriera and her male twin is a seeming digression: Ricciardetto is to be killed because he has disguised himself as his sister in order to win the love of a princess who had believed Bradamante to be male; he is then rescued by Bradamante's beloved, Ruggiero, who mistakes the brother for the sister. Orlando furioso rehearses the main paradigms of sibling relations - reciprocity, affection, competition, and alliance-building — reminding us, moreover, that sibling relationships are gendered.

Such expression, however, may be determined not only by the gender of characters depicted, but also by the author who creates them. In "When the Mirror Lies: Sisterhood Reconsidered in Moderata Fonte's Thirteen Cantos of Floridoro," Valeria Finucci interrogates some of the stock features of Renaissance romance and comedy, including opposite-sex twins, examining the implications of gendered authorship in the example of Moderata Fonte Tredici canti del Floridoro, ${ }^{2}$ which ostensibly casts two female twins as emblematic figures of law and order. The two sisters serve as the two faces of womanhood described in the poetry and culture of the time: one is the castrating female, and the other is the pliant, although often unavailable, object of male desire. In her essay, Finucci asks what aspects of sisterhood a woman author might summon in her writing and under what representational conditions does crossdressing enable a trasformation of the topos.

The women considered in the present essay are neither pacifists nor civic mothers. On the contrary, they conflate the civic and the personal, praising men for fighting or chiding them into battle by withholding their praise. For example, through their writings, Laura Terracina (Naples, 1519-1577) and Chiara Matraini (Lucca, 1515-1604) empower themselves as judges in the system of masculine military honour glorifying or vituperating as best fits their needs. What emerges from these and other writings by women about war is that praise and shame provide an effective tool through which women may guide men's military performance. Such power is enabled by the very gendering of war, whereby men are the undisputed protectors of women and are forced to take up arms on women's behalf.

\footnotetext{
2 The participation of women in the most popular genre during the Cinquecento-the chivalric romance-can no longer be ignored, thanks to Valeria Finucci, who both edits Moderata Fonte's Floridoro, first published in 1581, and provides an engaging introduction to the author and the romanzo cavallaresco "al femminile."
} 
The complexity of this universal truism - men fight to protect women-is most evident in the writings of Moderata Fonte who, in her dialogue on $\mathrm{Il}$ merito delle donne (The Worth of Women, 1592), deconstructs gender roles in war, by exposing art and literature as perpetuating social norms of sexual inequality. Fonte's response to the gendering of war is ultimately ambivalent, for she asserts that women should remain the peaceful sex by threatening to become its opposite, the literary legend of fighting women, the Amazon.

According to Fonte, men fight because they are inspired by a discourse of honour that is (re)produced through art. She tells us that famous men, including warriors, are celebrated in "statues, columns, and other similar constructions erected to their honour" (Fonte 1997 p. 227), ${ }^{3}$ just as they are the objects of memorial poems, lauding their virtue. One of Fonte's speakers recites a sonnet that praises a knight after his death in battle; warfare and specifically the knight's pursuit of honour are shown to provide nothing less than the security of the world: "But running too keenly, alas! At the heels of honor, he met his death. And dying, as he did, for him who had made him immortal, he relieved the world from fear, at the same time thrusting it into mourning" (Id., p. 229). ${ }^{4}$ Such poems and statues praising dead heroes do more than immortalize men; they also recruit new soldiers: "[poems] encourage others to give up their lives for their country, inspired by a noble hope to be so honored themselves" (Ibid.). Moreover, heroes inscribed in statuary and literary representations recall yet another literary ideal, the chivalric knight. The model male hero is, in fact, one of a textual past, "those knights one reads about, who carried off their victories through the courage of their heart and the might of their arm" (Fonte 1997, p. 230).

What is at stake for masculinity is that literary knights, marble statues, and historic heroes are nearly interchangeable discursive forces of honour that stand in contrast to the short-comings of contemporary men. In particular in Fonte's summation, Venetians were losing wars due to their enemies' use of artillery. Fonte's female interlocutor states that, in order to correct what is no less than men's gender failure, women must go to war themselves: "I'd like to see us women

\footnotetext{
3 "Si soleano drizzar statue, colonne e simili edifici a perpetua memoria della loro fama" (Fonte 1600, p. 139).

4 “Ma troppo ahimé, d'onor seguendo l'orme / More, e morto per lui, che' l fé immortale / Trasse il mondo di dubbio, e "l pose in pianto / come quelli che spendono la loro vita per la patria" (Ibid.).
} 
arming ourselves like Amazons of old and going into battle against these men" (Ibid.). ${ }^{5}$

The chivalric knight represents men who will be emasculated by warring viragos, a uniquely aggressive response to men's unmanly neglect of wartime duties as defined by a mediated literary exemplum. Furthermore, her apparently radical stance closely connects gender and warfare, perpetuating a war ideology that glorifies masculine military honour and identifies women as the vulnerable sex. With this paradigm in mind, we might use Fonte's writings as a springboard for our investigation of two writers who preceded her. As will now be discussed, Terracina and Matraini, in divergent and innovative ways, raise their voices in the war machine while still calling on men to prove their masculinity in arms.

For example, Terracina's oeuvre includes eight volumes of poetry, published between 1548 and 1567, as well as a ninth book of poems still in manuscript form at her death. The third and eighth books are two discrete discorsi on the Orlando furioso. Terracina's Discorsi like Ariosto's epic, is composed of 46 canti, each containing one preliminary ottava, usually dedicated to a patron or important figure, followed by seven additional ottave. The final lines of each of the seven ottave correspond to the lines in the first ottava in each of Ariosto's canti-that is, the first six ottave in Terracina's commentary always end with a single line from Ariosto.

In the preface to her third book, Il Discorso della S. Laura Terracina sopra il principio di tutti $i$ canti di Orlando Furioso, she includes a poem to Ludovico Dolce, the sixteenth-century editor, art critic, and sometimes literary agent, in which she demonstrates her exceptional position with regard to the gendering of war. Terracina highlights her uniqueness as a woman by writing about war, a matter that is complicated by the fact that we specifically know that she is not the only woman to do so. In her poem to Dolce, Terracina asks for "pardon" for her "virile" language, "E se la lingua mia fu si virile / Perdon vi chieggio." In canto XIV of the Discorso — which praises Pope Julius III as a warlike prince-, she again addresses the matter of war as a masculine subject not suitable for women. She asks if her amorous poetic style can speak of anger and hate, if her feminine wisdom can follow the path of Mars, and if her pen can be virile enough to continue without a guide:

\footnotetext{
5 "Vorrei che fusse quel tempo-disse Leonora — che vorrei che noi donne tutte si armassimo come quelle antiche Amazzoni ed andassimo a combattere contra questi uomini" (Ibid.).
} 
A che condutto il mio amoroso stile

A parlar d'ira, e ragionar di morte,

Come potrà l'ingegno feminile

Seguir di Marte il fier camin si forte?

Sara la penna mia tanto virile,

che voglia a cio resister senza scorte

Veggio c'havranno ugual pena e dispitti

Ne i molti assalti, e'n si crudel conflitti

(Terracina 1553, fols. 24v-25r).

Terracina recalls the dominant gender ideologies that restrict women's participation in war, specifically, the issue of whether women are notable enough to write about it. Despite the fact that some early modern women wrote about arms, war was — and arguably still is - gendered as a man's subject. Women poets, she suggests, are relegated to appropriate themes of love, and Terracina slyly inscribes herself in this discourse, discussing her "amoroso stile" and "ingegno feminile." Yet Terracina's Discorso is certainly not written with "amoroso stile": It makes social critiques of various contemporary groups, including courtiers, captains, and unfaithful men and women. Furthermore, this feminine posture of vulnerability contrasts the masculine role of protector, as emphasized by the rhyming words of "forte" and "scorte;" an effective reminder that women need strong men who guide them; however, our poetess is without a guide as she ventures into the masculine world of war, both real and poetic.

The following canto (XV) is dedicated to cardinals and bloody captains, "Ali Cardinali et Sanguinosi Capitani," and is a commentary on the wars contemporary to Terracina's lifetime. The canto argues that men, not women, have called for war and that therefore women should be spared. The soldier who has killed women leaves other men as daughterless fathers and in effect collects unholy "trophies of dresses and skirts."

Even though women are faultless with regard to the origin of war, men kill them futilely in their pursuit of fame. Terracina's protest then raises the stakes by calling for change, seeking to redefine the terms of praiseworthy warfare. Gazing back to her previous canto, in which she had insisted on women's vulnerability, Canto XV describes the current wars as heinous battles where men do not protect but rather kill women, and her invective against military captains is precisely at odds with what the epic poet is supposed to do for fighting men.

She immortalizes the captains not for their honour but for their cruelty and impiety: "Qual sia soldato pur ch'osservi legge / Che non sia contro donna un 
Leopardo?" (Ibid., fol. 26r). In regard to the terms that she has established regarding masculinity and war, men have failed in their gender role as women's protectors, and she takes recourse in her ability to praise or vituperate them accordingly.

One of the most original and interesting aspects of Terracina's Discorso is its form of literary proto-feminism: as a woman writer, she not only appeals to but positively commands her women readers to break out of the confines of traditional female roles-such as a keeper of the household, enshrined in domesticity - and to embrace the virtues of study and scholarship, so that they may then be judged on the same footing as men in the pursuit of intellectual excellence. These concerns surface in several parts of the Discorso and collectively constitute a kind of 'apologia for the woman writing.' Terracina is particularly innovative in her exhortation to women readers of the Discorso to follow her own example and take up the pen as means of expression and retaliation against the male-dominated literary sphere.

We see this especially in her canto XXXVII, dedicated to the poet Veronica Gambara, in a change to Ariosto's canto, in which he singles out Vittoria Colonna as the greatest woman writer of the time:

Alla eccell. Signora Veronica da Gambara

Deh fosser molte al mondo come voi,

Donne che a scrittor metter freno,

C'ha tutta briglia vergan contro noi

Scritti crudeli, e colmi di veleno;

Che forsi andrebbe in sino ai liti Eoi

Il nome nostro, e 'l grido d'onor pieno;

Ma perchè contra a lor nulla si mostra,

Però tengono vil la fama nostra (Ibid., fol. 59r)

In the Furioso, Colonna is praised as a writer of universally acknowledged excellence, but primarily as a loyal wife. "Terracina's emphasis are markedly different [...] Veronica Gambara, who take the place of Vittoria Colonna, is lauded not for her fidelity to the memory of her husband, but purely for the literary virtù that has the power to confound the 'cruel and murderous slanders' men direct against women" (Cox 1997, p. 137).

Six years after Laura Terracina's Discorso was published, the first book of Chiara Matraini_Rime e prose (Poems and Prose) — was printed in 1555 in her home city of Lucca. It consists of her first Canzoniere amoroso and two prose pieces: an epistolary treatise on the defence of love, addressed to an unidentified man 
(indicated only as M.L.), and the Orazione dell'arte della guerra (Discourse on the Art of War), an exercise in defence of the strategic capacity of "a condottiero," regardless of the battle, written in praise of man's cognitive qualities. The lack of attention given to this discourse on war by both by her sixteenth-century contemporaries and present-day scholars suggests how uncomfortable readers are with a woman's text praising war. It is, to my knowledge, the only oration or treatise praising war written by a woman in the Italian Renaissance. It bears the markings of a vernacular humanist treatise: Latinizing syntax, frequent classical citations, and complex rhetorical strategies.

Yet her Discourse differs from the humanist prose on war written by other female authors such as Laura Cereta, who complains about the brutal effects of war, finding only futile devastation and death. Matraini's work is instead an unapologetic treatise on the glories of war, and it is a persuasive text, addressed to "signori Academici," students of poetry and philosophy whom she wishes to incite to take up arms and fight. Matraini, like Terracina, immediately acknowledges the uniqueness of a woman addressing war. But unlike Terracina, Matraini states that there is a moral imperative for her to communicate her thoughts on the virtues of war. Her ambition to venture, like a male writer, into the terrain of humanistic culture and philosophy is also reflected in this Orazione, in which she elaborates on man's greatness through his intellect, one of the main themes of the Renaissance. Matraini's text is animated by the desire and ambition to attempt the traditionally masculine genre of humanistic and philosophical culture (Matraini 1989, pp. 101-102):

Mentre che del troppo audace Fetonte i funesti e lacrimevoli avvenimenti, causati da soverchio giovanile ardire meco stessa considero, salutevole essempio a chiunque osa altra le proprie forze tentare, e della notabilissima sentenza di Chilone, famosissimo saggio di tutta la Grecia reputato, mi ricordo, quasi vile e noiosa cicala con l'asprezza delle mie roche voci uscir non oso, nobilissimi studiosi nostri signori Accademici, i cui divini spiriti ed elevati ingegni con la dolce armonia de' lor soavi concetti degni sono da gli antichi e sapienti filosofi d'esser udito. Ma poscia ricordandomi quanto laudevole sia in giovanile età a gli onesti comandamenti de' maggiori suoi obediente e presta concedersi, posposta ogni altra scusa quantunque lecita, per esser donna, e accettabili fosse, non ho voluto, quasi da vilissima pigrizia oppressa, biasmevolmente star pertinace [...] Mentre che scarca d'ogni altra sollecita cura, con la fidata scorta del mio lodato e sapientissimo Atlante, per gli cui degni essempi spero dovere ancora, ove le crude inesorabili Parche il vital filo in erba invidiosamente non mietino, da queste oscure e basse nebbie chiaramente allontanandomi, fare a l'empia e cruda morte disusati inganni, le dotte carte de gli antichi e famosi scrittori intentamente considerò niuna altra cosa doppo il supremo 
studio della bella e universal Filosofia, più salutifera né più eccellente fra tutti gli uomini mortali esser ritrovo, che l'arte convenevole e santa della giustissima e potente virtù militare.

Although Matraini's humanist prose may seem distant from the verse of Terracina, both women share the common strategy of turning to their gender as the origin of their rhetorical strength, calling on their right as women to demand that men perform a "correct" masculinity. Such a strategy allows these writers to transcend the boundaries of "proper" feminine literary genres as they ironically confine women to the role of the vulnerable sex. Thus, the Discorso occupies a unique place in mid-Cinquecento writing, opening the possibilities for later writers such as Moderata Fonte and Lucrezia Marinella to enter the arena of the epic genre.

Moderata Fonte was not the first Renaissance woman writer to occupy herself with a literary genre codified by men. As has been frequently asserted, there was a 'numero sorprendente' of women who published chivalric romances prior to and after her. However, more important than their amount, is the fact that the census includes such highly-regarded authors as Laura Terracina and Tullia d'Aragona, who published a rewriting of Guerin Meschino in 1560. As a matter of fact, their audacity to participate in this literary genre was already recognized in the seventeenth century, albeit not without a note of denigration.

One reason why chivalric romance in its Ariostan formula appealed so strongly to women was without doubt the innovative quality of its representation of women, especially its creation of the figure of the female knight, one of the most fascinating and distinctive new literary types of the age. We can list many reasons why women might have been attracted by the chivalric romance. Apart from the more obvious one-the popularity of the genre itself-, it should be noted that, unlike lyrical poetry, chivalric romance allowed women to deal with love without being themselves closely bound to or identified with the amorous values of their characters, thus preserving their reputation. And if male authors could avail themselves of other books in their research-not all had been soldiers, for example_-, why then could women not do the same?

Building on the precedent of Matteo Maria Boiardo's Orlando innamorato (14831495), Ariosto includes two female knights in the Orlando furioso: the Christian Bradamante, the protagonist of the poem's principal love story, destined with her husband, Ruggiero, to found the dynasty of Ariosto's patrons, the Este; and the slighter but striking figure of Marfisa, Ruggero's sister, who, like him, starts the poem a pagan but converts by the end. Especially in his last version of the poem (1532), Ariosto draws out the proto-feminist implications of guerriera figure 
overtly, arguing in two canto proems for women's capacity to equal men in their achievements if given the opportunity and citing as a modern archetype of female virility Vittoria Colonna, who was emerging in these years as a poet of note.

In the poem, the depiction of both women - particularly Risamante, the female hero - and men, namely the other knights, who are all "cavalieri antieroici e maschi falliti" (Finucci, 2006, p. xxvii) is very interesting. As an author, Fonte seems to have had little interest in the masculine concept of honour, which was becoming an increasingly popular motif in the epic, as can be seen in Tasso's heroes, who are moved by a sense of Christian honour and suffer from consequent guilt when they stray from what should be their primary motivation). Even the action of the poem's hero, Floridoro, can be characterized — at least once he falls prey to loveas infantile. Finucci sees this as Fonte's reaction to the sexual ideology that relegated the knight to an active, heroic role, while the maiden was traditionally placed in a passive position, in need of defense. Fonte's female characters, on the contrary are not only depicted in a variety of roles but are of varied, often contradictory, typology, as in the case of the twin sisters Risamante and Biondaura. The analysis of the conflict between the twin sisters is also intriguing. For example, Fonte neither follows the Ariostean tradition-where twins are usually of the opposite sex-, nor the pattern where the other sister is wicked-e.g., Alcina as opposed to Logistilla. She is unwilling to discard women characters with nonchalance-thus the lack of abandoned women in the text. Fonte's female characters-and, once more, especially Risamante and Biondaura - are not only described in a variety of roles, but they embody different and often contrasting types.

Finally, Fonte, as a woman, makes alternative (i.e., non-traditional) choices in the development of her poem as she was hindered, often at the same point, from reaching a successful conclusion due to the weight of cultural constructs, which had become routine in the models available to her:

To enter among the diverse paths

and among the immense roads I desire and dare-

onto which of them must I now send forth my verses?

Fonte elaborates female models made available by Ariosto's poem, developing them in unexpected ways. Circetta is one such figure in the Floridoro, a mixture of Ariosto's Alcina-without her overt sexual nature, yet with her magically

\footnotetext{
6 "Io, che d'entrar fra li sentier diversi / e fra l'immense vie bramo e ardisco, / Per qual hor deggio incaminar miei versi," Tredici canti del Floridoro, prefazione (Fonte 2006, pp. 49-50).
} 
prolonged youth-, Logistilla, and Melissa. Circetta painfully embodies the difficulties of a woman writer working in the romance genre. Tied down by the history of the epic, Circetta, like Alcina, transforms failed knights into trees, is subject to the vagaries of love and, if that were not enough, she fulfills a similar function to that of Ariosto's Melissa, revealing the future shape of a dynasty not yet come into being. However, Fonte manipulates such a well-known figure so that Circetta carries greater significance than as a mere bearer of dynastic messages for the courtly audience. At first sight, she might be viewed as a prototype for the model that will be developed in Il merito delle donne, the figure of Corinna who eschews men to the point of refusing marriage and vaunting the possibility of a fulfilling single life. However, she soon falls in love, which may remove her from her previously enforced single status, though the episode is far from complete.

Fonte makes a determined effort to rewrite myth, to valorize female achievement in the context of a universal story, to tell the other side-here the relationship between Circe and Ulysses. By overturning the various male versions of the story, Fonte emphasizes the fictionality of such myths and their openness to interpretation so that they can be challenged and perhaps eventually replaced by a female version.

The Circe episode is partially subjected to a feminist reading, both regarding the point of view from which Fonte recounts her story and its connection to the proem of the canto on the "bestiality" of contemporary men. As Virginia Cox argues: "it does not seem unfounded to detect a proto-feminist impulse at work in Fonte's transformation of the maga from seductress to guileless virgin; certainly, this transformation very effectively short-circuits the implicitly misogynistic allegorical logic of more conventional versions of the episode, which 'naturally' turn to the literal and deceptive allure of the sense" (Cox 1997, p. 143).

It is significant that women's interest in the epic gained momentum in the period after the publication of Floridoro, and a number of women writers composed epic poems in the seventeenth century, although there was a tendency to imitate Tasso rather than Ariosto. For example, Lucrezia Marinella, author of L'Enrico overo Bizanzio conquistato (published in 1635), knew the Floridoro, but, in order to be taken seriously, did not consider it the most elevated and dignified model of the genre. Marinella took up this subsequent trend as a point of departure for her own foray into the genre, preferring to imitate the Gerusalemme liberata, in the increasingly dogmatic climate of Counter-Reformation.

Marinella, whose major feminist work Le nobiltà et eccellenze delle donne (On the Nobility and Preeminence of Women) was published in the same year as Il merito delle donne, had read Floridoro. Her attention was drawn to the proem of canto IV, the 
most outspoken in favour of women. Marinella quotes from it the entire second stanza. Fonte had optimistically stated that women - if only a few-had managed to succeed in becoming soldiers, and in letters, women had proved themselves to be at least the equal of men. Marinella is not so convinced by this argument:

But in our times there are few women who apply themselves to study or the military arts, since men, fearing to lose their authority and become women's servants, often forbid them even to learn to read or write. (Marinella 1999, p. 79) ${ }^{7}$

Marinella recognizes, however, that Fonte's idealistic picture is tempered by the poet's realization that access to education was essential if more women were to take on more active social and cultural roles: "Non saria nelle imprese alte e leggiadre / Al frate inferior né disuguale" (4.4, 3-4). Marinella extends this line of reasoning, quoting stanza 4 in its entirety:

I would like these men to try the experiment of training a good- natured boy and girl of about the same age and intelligence in letters and arms. They would see how much sooner the girl would become expert than the boy and how she would surpass him completely. Moderata Fonte, though content with proving them equal, writes this in Floridoro (Marinella, 1999, p. 80). ${ }^{8}$

Marinella's critique of the overt ideology of the Floridoro comes from a different perspective: the superiority of women over men, which challenges the very basis of civil society. Fonte, nevertheless, operates in a subtler manner, more suggestive than prescriptive. She puts on display a number of behaviors with some commentary and demonstrates that male oriented genres can be subverted to feminist uses. L'Enrico belongs to a poorly represented genre in women's writings: only two more epic poems were published by women in the seventeenth century, namely Scanderbeide by Margherita Sarrocchi (Rome 1606 and, in complete version, 1623), and Ascanio errante by Barbara degli Albizzi Tigliamochi (Florence, 1640).

\footnotetext{
7 "Ma poche sono quelle che dieno opera a gli studij overo all'arte militare in questi nostri tempi. Percioché gli uomini a guisa d'insolenti tiranni proibiscono loro questo, temendo di non perdere le signorie e di divenir servi delle donne. E però vietano a quelle ben spesso ancho il saper leggere e scrivere" (Marinella 1601, fol. 11v).

8 "Io vorrei che questi tali facessero una esperienza tale che essercitassero un putto e una fanciulla d'una medesima età e ambiduoi di buona natura e ingegno nelle lettere e nelle armi che vederebbono in quanto minor tempo più peritamente sarebbe instrutta la fanciulla del fanciullo e anzi lo vincerebbe di gran lunga. La qualcosa lasciò scritto Moderata Fonte nel suo Floridoro, ma ben è ver che ella si contentò che devenissero eguali” (Marinella 1601, fol. 12r).
} 
Although the epic was a tried and trusted genre, it continued to attract the attention and efforts of primarily male writers: Rinaldina Russell reminds us that Antonio Belloni counted "at least ninety-eight poems in imitation of Tasso's Jerusalem" (Russell 1994, p. 234) printed during the seventeenth century. Marinella's epic differs from the other two women-authored ones in its physical appearance, printed as it is in duodecimo (as opposed to the much more imposing quarto of the others) and devoid of any prefatory poems praising the writer, her choice of topic, or her ability in dispatching the work.

Furthermore, Marinella dedicates Enrico to the reigning doge of Venice, Francesco Erizzo (1631-1646) and the Serenissima Venetian Republic. By marking her allegiance to Venice, Marinella advances her implicit argument that she represents the point of view of her city on these events. Her voice emerges as choral, expressing the position of a community, as evidenced by the usage of first person plural pronouns, verbs, and adjectives, and the important gender continuity of a woman narrator and a woman-identified city.

As Niccolò Zorzi has recently highlighted, following the victory at Lepanto (1571), Venetian presses produced two historical prose narratives of the Fourth Crusade, namely Paolo Ramusio's De bello Constantinopolitano (published in Italian in 1604, in Latin in 1609 and again in 1634) and Andrea Morosini's L'acquisto che la Repubblica di Venetia confederata con Prencipi Francesi, fece dell'Imperio di Costantinopoli (1627). Although Marinella utilized at least one additional_and non-Venetiansource, poetically she establishes her authority on matters of content from the very beginning of her text, proposing that her poem puts forth a version of the events that coincides with the preferred —and, as we will see, official_-Venetian one. Furthermore, in order to corroborate her position as a narrator within the poem, she employs some standard rhetorical commonplaces. Therefore, both the rhetorical questions and the direct references to her presence and role as a narrator throughout the text allow her to become invested with authority. By doing so, she follows an approach common in early modern Italian texts, namely, a simultaneous assertion of authorship and of her diminished importance and subordination to her subject matter.

When we consider early modern epic poems and even romances, Marinella's canonical predecessors offer numerous examples of women who carry out important structural and ideological roles: her women warriors - the Venetian Claudia and the Byzantine Meandra and Emilia_-are reminiscent of Clorinda and Gildippe in Tasso's Gerusalemme liberata and Rosmonda in Sarrocchi's Scanderbeide; the wise, magician-like revealer of things to come, Erina, reminds us of Alcina, 
Melissa, and Logistilla in Ariosto's Orlando furioso and Armida in Gerusalemme liberata, as well as Risamante in Fonte's Floridoro and Calidora in Scanderbeide. It is on Erina that Marinella bestows the most authority. Not only does she utter more lines in reported speech than any other character in the poem, surpassing even the doge Enrico Dandolo himself, but Erina also serves as a reinforcement for the narrator and her role in the poem, referring to her on four separate occasions. These references set in motion a circle of mutual corroboration: as Erina underscores Marinella the narrator's role and pre-eminence, the character herself emerges as a stronger and more authoritative presence for the implied reader.

Yet Erina is singular on many levels. Erina in effect emerges as the co-author of the text before our eyes, and Marinella as one of many writers who represent Venetian history. She is crucial as the revealer of past, present, and future events as well as the learned person who explains hidden historical and geographical features. As a figure of authority within the plot, Marinella voices opinions through her that underscore the fact that the poem was written by a Venetian woman.

Later on, while flying over Venice and illustrating the city's geographical features and glorious history, Erina again refers to the narrator:

Look at a beautiful mermaid come out of the waves, she's pretty and still young, and she emitts beautiful and joyful notes from her learned cithara that gild the seaweeds and shores all around. See some green laurel entwined in her blonde hair... (Marinella 2009, 22.28, p. 328). ${ }^{9}$

Marinella's choice to refer to her heroine as a blonde sirena is a quietly revolutionary move: it is in keeping with the epic tradition, but it redefines a deeply negative (because fundamentally feminine) mythical presence as the narrator. Furthermore, Marinella/the narrator as mermaid is presented as being 'wooed' by the 'sacred muses.' Suddenly, the 'programmatically ascetic' Marinella objectifies herself in a highly sexualized manner, the subject of homoerotic attention that is revealed by the female character endowed with the most relevance in the poem. In an ambiguous manner that is also typical of her writing, Marinella makes a radical statement that is at once a pronouncement of the power of poetry over the narrator and an avowal that her poem can speak with a plural, city-wide, and male-and-female (hence neutral) voice.

9 "Mira vaga sirena uscir dell'onde, / Bella, leggiadra e pargoletta ancora, / Temprar con dotta cetra alte e gioconde / Note, onde l'alghe intorno e i liti indora...” (Marinella 1635, p. 518). 
Erina is part of this tradition, and, because Venier is related to her, he is also a link in this chain of knowledge and deserves to know his city's future as well as his own, painful though that proves to be. Venier is instrumental to the crusaders' victory and, by extension, to Venice's future glory. The image employed by Marinella to describe Erina's action is aggressive and masculine; the contrast between her decisive act and Venier's reaction could not be starker: he is chilled by what he sees.

What Erina and Venier observe in the canto that follows is a series of images that narrate the past history of Venice, starting with the city's founding (7.2-16). This offers a strong support for the authority of Erina's narrative of past doges and naval battles: it extends beyond her personal and familial history, reaching to the most glorious and important events of Venice's own past, which seems to follow closely those painted on three walls of the Hall of the Great Council after the 1577 fire by the likes of Veronese, Tintoretto, Francesco Bassano, and Palma il Giovane. As Giorgio Tagliaferro has remarked, it is through these events that "si realizza il senso profondo della predestinazione di Venezia" (Tagliaferro 2006, p. 341). Daria Martelli further notes that official depictions of Lepanto promoted its myth "ma nello stesso tempo, rappresentando l'evento, davano forma alle emozioni di tutto un popolo e operavano una catarsi collettiva" (Martelli, 2011, p. 51).

In her explanation to Venier, Erina singles out two military events that would have been extremely familiar to Marinella's implied readers, due to their importance and chronological proximity: the battle of Lepanto (1571). As Dante in the Commedia, Ariosto-in the Orlando furioso and Tasso in the Gerusalemme liberata, Marinella's chronological standpoint allows her character to prophesy the victorious conclusion of the expedition and, more importantly to Venier, his death in battle (7.62). Any reference, however covert, to the history of Venice shows Marinella's intention to write an epic true to its genre, despite her gender and republican affiliation. The parallels to the Hall of the Great Council painting cycle bestow authority on Erina (and thus on Marinella) by grounding her knowledge of the events on a state-sponsored and prominently located pictorial cycle, thus bolstering her right to narrate her city's past and future. What Erina explains compounds the number of lines she speaks; form and content contribute to her transformation into the author's own most powerful spokesperson. Marinella's voice is authoritative yet, appropriately for her historical moment, attracted and distanced through a character in her narrative.

Marinella would not have been able to write her poem without the military prowess that Venetian fighters offer her and the rhetorical exempla upon which she 
models her narrative. While elaborating on the former and building on the latter, Marinella the narrator strikes a balance between assertiveness and homage to past forms, between the needs of the genre and the desire to express her opinions as a narrator and a woman, and between a neutral, plural 'noi' and the men and women that compose her ensemble.

The attention to the epic paradigms in which the female warrior is the friend/ beloved/ wife on equal terms with her male counterpart support the view that in Italian Renaissance literature the militarization of the woman necessarily does not bring about the emasculation of the man, nor is it the woman warrior who "feminizes" the knight by depriving him of his martial valour and identity.

\author{
Sandra Plastina \\ Università della Calabria \\ sandraplastina@hotmail.com
}

\title{
BIBLIOGRAPHY
}

Aragona, T. d' (1560): Il Meschino, altramente detto il Guerrino, Venetia: Gio. Battista et Melchiorre Sessa.

Bethre Elshtain, J. (1995): Women and War, with a new epilogue, Chicago and London: Chicago University Press.

Cox, V. (1997): "Women as Readers and Writers of Chivalric Poetry in Early Modern Italy," in Z. Baranski et alii (eds.), Sguardi sull'talia: miscellanea dedicata a F. Villari, Leeds: Society for Italian Studies, 3, pp. 134-145.

- (2011): The prodigious Muse. Women's Writing in Counter-Reformation Italy, Baltimore: The John Hopkins University Press.

ERNST, G. (2014): "Non solo la conocchia e il fuso. Figure di donne guerriere nel Rinascimento," B@belonline, 16/17,pp.159-167.

FINUCCI, V. (2006): "When the Mirror Lies: Sisterhood Reconsidered in Moderata Fonte's Thirteen Cantos of Floridoro," in N.J. Miller, N. Yavneh, (eds.), Sibling Relations and Gender in the Early Modern World, New York-Aldershot: Ashgate, p. 116-128.

FONTE, M. (1600): Il merito delle donne, scritto da Moderata Fonte in due giornate, ove chiaramente si scuopre quanto siano elle degne e più perfette de gli buomini, In Venetia: presso Domenico Imberti.

— (1988): Il merito delle donne: ove chiaramente si scuopre quanto siano elle degne e più perfette de gli uomini, ed. A. Chemello, Mirano (Venezia): Eidos.

- (1997): The Worth of Women: Wherein is clearly revealed their Nobility and their Superiority to Men [l merito delle done (1592)], ed. and trans. V. Cox, Chicago and London: University of Chicago Press.

- (2006): Floridoro: A Chivalric Romance, ed. V. Finucci, trans. J. Kisacky, Chicago and London: Chicago University Press. 
MARINELLA L. (1601): La nobiltà et l'eccellenqa delle donne co' diffetti et mancamenti degli buomini, Venetia: Gio. Battista Ciotti.

- (1635): L'Enrico, overo Bisantio acquistato, poema heroico, Venetia: Ghirardo Imberti.

- (1999): The Nobility and Excellence of Women, and the Defects and Vices of Men, trans. A. Dunhill, Chicago and London: Chicago University Press.

- (2009): Enrico, or Byzantium Conquered. A Heroic Poem, trans. M.G. Stampino, Chicago and London: Chicago University Press.

Martelli, D. (2011): Polifonie. Le donne a Veneziia nell'età di Moderata Fonte (seconda metà del secolo XVI), Padova: Cooperativa Libraria Editrice della Università di Padova.

MATRAini, C. (1555): Rime e prose, Lucca: Busdraghi.

- (1989): Rime e lettere, crit. ed. G. Rabitti, Bologna: Commissione per i testi di lingua.

PAPP, J. (2016): "Female body-male body: The valiant Hungarian women of Eger and Szigetvár from the 16th century in historiography, literature, and art," Cogent Arts \& Humanities, 3, pp. 1-17.

Piccolomini, E.S. (1532): Historia Bohemica, Cologne: Gotthard Hittorp.

REINLE, C. (2000): “Exempla weiblicher Stärke? Zu den Ausprägungen des mittelalterlichen Amazonenbildes," Historische Zeitschrift, 270, pp. 1-38.

Russell, R. (1994): Italian Women Writers. A Bio-bibliographical Sourcebook, Westport, Connecticut-London: Greenwood Press.

SArrocchi, M. (1606): La Scanderbeide poema heroico, Roma: Lepido Facij.

STOppino, E. (2013): "Early Modern Amazons: Teaching Conflict in Representation," in K. Nelson (ed.), Attending to early Modern Women. Conflict and Concord, Newark: University of Delaware Press, pp. 207-218.

TAgliaferro, G. (2006): "Martiri, eroi, principi e beati: i patrizi veneziani e la pittura celebrativa nell'età di Lepanto," in M. Chiabò and F. Dogli (eds.), Guerre di religione sulle scene del Cinque-Seicento, Roma: Torre d'Orfeo, pp. 337-375.

TAsso, T. (2000): Jerusalem Delivered-Gerusalemme liberata, trans. A.M. Esolen, Baltimore and London: The Johns Hopkins University Press

Terracina, L. (1553): Discorso sopra il principio di tutti $i$ canti d'Orlando Furioso, Venetia: Giolito.

WARING, C. (2007): “Laura Terracina's Feminist Discourse (1549). Answering the Furioso," in M. Boria and L. Russo (eds.) The Investigating Gender, Translation and Culture in Italian Studies, Leicester: Troubador Publishing, pp. 151-168. 